\title{
ПРАВОВОЕ РЕГУЛИРОВАНИЕ КАРШЕРИНГА
}

\section{LEGAL REGULATION OF CARSHERING \\ T. Mayboroda}

Summary: The article analyzes the legal regulation of a short-term lease of vehicles (car sharing). The author comes to the conclusion that at the present time there is no common understanding of the nature of the investigated relations. There are no special rules on the car sharing agreement in civil law, although there is a need for this. The author puts forward some proposals for changing the current legislation to resolve the problems of the car sharing agreement under consideration.

Keywords: car sharing, short-term vehicle lease agreement, civil law, freedom of contract, rental agreement.

\author{
Майборода Татьяна Юрьевна \\ К.ю.н., Курганский государственный университет \\ xxx092020@gmail.com
}

Аннотация: В статье проводится анализ правового регулирования договора кратковременной аренды транспортных средств (каршеринга), практики его применения, а также судебной практики в данной области. Автор приходит к выводу, что в настоящее время еще не сложилось единого понимания природы исследуемых отношений. В гражданском законодательстве отсутствуют специальные нормы о договоре каршеринга, хотя необходимость в этом имеется. Автором выдвигаются некоторые предложения по изменению действующего законодательства для разрешения рассматриваемых проблем договора каршеринга.

Ключевые слова: каршеринг, договор краткосрочной аренды транспортного средства, гражданское законодательство, свобода договора, договор проката.

средства конкретизируется в Приказе Департамента транспорта и развития дорожно-транспортной инфраструктуры г. Москвы от 2 сентября 2015 г. № 61-02-283/5, согласно которому «услуга каршеринга - это предоставление транспортных средств в краткосрочную (до 24 часов) аренду на основе поминутной тарификации физическим лицам для целей, не связанных с осуществлением такими физическими лицами предпринимательской деятельности» [4].

Таким образом, исходя из дефиниции [3] можно предположить, что каршеринг - договор аренды транспортного средства, однако, второй правовой акт [4] указывает на договор аренды в целом, без конкретизации. Правовое регулирование договора аренды в целом, и транспортного средства в частности, содержится в главе 34 Гражданского кодекса РФ. В содержании данной главы можно выделить два вида договора аренды, которые применимы к регламентации отношений, возникающих при каршеринге. Во-первых, это договор аренды транспортных средств, а именно «аренда транспортного средства без предоставления услуг по управлению и технической эксплуатации», который регламентируется ст. 642 - 649 ГК РФ [5]. Во-вторых, договору каршеринга так же свойственны признаки договора проката, регламентируемого положениями ст. 626 - 631 ГК РФ [5]. Однако, арендодатели транспортных средств предпочитают не использовать последний для регламентаций отношений каршеринга.

Вышеуказанное обстоятельство объясняется не только спецификой транспортного средства как предмета гражданско-правового регулирования в отношения, возникающих при каршеринге, но и специфике порядка и формы заключения договора. 
Договор проката, на первый взгляд, точно отражает специфику субъектов и цели, для которых заключается договор каршеринга (арендодатель - профильная компания, арендатор - физической лицо, цель - не связанная с осуществлением предпринимательской деятельности). Так, согласно ч. 1 ст. 626 ГК РФ «по договору проката арендодатель, осуществляющий сдачу имущества в аренду в качестве постоянной предпринимательской деятельности, обязуется предоставить арендатору движимое имущество за плату во временное владение и пользование. Имущество, предоставленное по договору проката, используется для потребительских целей, если иное не предусмотрено договором или не вытекает из существа обязательства» [5].

Однако, договор проката является публичным договором, и следовательно, предполагает соблюдение требований, предусмотренных ст. 426 ГК РФ, в том числе арендодатель «не вправе оказывать предпочтение одному лицу перед другим лицом в отношении заключения публичного договора» [6]. В тоже время ограничения или запреты в возможности заключения договора каршеринга могут быть обоснованы спецификой объекта аренды - автомобиля, который относится к источникам повышенной опасности и обусловливает соблюдение требований безопасности дорожного движения. Например, логичным представляется отказ каршеринговой компании в предоставлении автомобиля в аренду лицу, которое многократно привлекалось к административной ответственности за нарушение правил дорожного движения (по аналогии с отказом банка в предоставлении кредита лицу с «плохой» кредитной историей).

Кроме того, установленные законом права и обязанности сторон для договора проката не во всех случаях подходят к правам и обязанностям, вытекающим из существа договора каршеринга. Речь идет о положениях ст. 627, 628 ГК РФ, согласно условиям которых арендатор вправе отказаться от договора проката в любое время, письменно предупредив о своем намерении арендодателя не менее чем за 10 дней (п. 3 ст. 627 ГК РФ), а арендодатель, заключающий договор проката, обязан в присутствии арендатора проверить исправность сдаваемого в аренду имущества, а также ознакомить арендатора с правилами эксплуатации имущества либо выдать ему письменные инструкции о пользовании этим имуществом (ст. 628 ГК РФ) [7].

Специфика заключения каршерингового договора, его исполнения и прекращения связывается с использованием новых технологий: договор каршеринга на современном этапе является примером смарт-контракта, который заключается и прекращается дистанционно путем регистрации пользователя в соответствующей программе (приложении), в связи с чем между пользователем такого приложения и каршеринговой компанией возникает одновременно целый ряд обязательств из лицензионных и пользовательских соглашений [8]. И хотя процесс осмотра автомобиля происходит - он носит односторонний характер, арендатор проверяет состояние транспортного средства на месте его стоянки (любое общественное место, указанное на карте в приложении компании арендатора), а краткосрочность аренды не предоставляет возможности соблюдения указанных для договора проката сроков.

В настоящее время в практике сложились два основных подхода в сфере заключения договора каршеринга:

1. Договор аренды транспортного средства без экипажа. Например, «Яндекс. Драйв», «YouDrive» и «Anytime» предлагают заключить договор аренды транспортного средства без экипажа [9].

2. Договор присоединения (к договору аренды транспортного средства без экипажа). Например, «Делимобиль», «Car 5» и «BelkaCar».

Так, согласно преамбуле договора ООО «Каршеринг Руссия» (Делимобиль) указано, что он не является ни договором проката, ни публичной офертой, а представляет собой договор присоединения в соответствии ст. 428 ГК РФ [10].

Отсутствие единообразия связано с недостаточностью нормативно-правового регулирования каршеринга, а также официального толкования в правовых позициях судов. Анализ судебной практики позволяет прийти к выводу о том, что в сфере договора аренды в целом и транспортных средств в частности действуют два основополагающих судебных решения: Постановление Пленума Верховного Суда Российской Федерации от 26 июня 2018 г. № 26 «О некоторых вопросах применения законодательства о договоре перевозки автомобильным транспортом грузов, пассажиров и багажа и о договоре транспортной экспедиции» [11] и Постановление Пленума Высшего Арбитражного Суда Российской Федерации от 17 ноября 2011 г. № 73 «Об отдельных вопросах практики применения правил Гражданского кодекса Российской Федерации о договоре аренды» [12]. Однако, ни одно из вышеуказанных судебных разъяснений не вносит ясности в вопрос каршеринга.

Не в полной мере для регулирования договора каршеринга подходят действующие положения об аренде транспортного средства без предоставления услуг по управлению и технической эксплуатации. Например, согласно ст. 644 ГК РФ «арендатор в течение всего срока договора аренды транспортного средства без экипажа обязан поддерживать надлежащее состояние арендованного транспортного средства, включая осуществление текущего и капитального ремонта» [5], а в ст. 645 ГК РФ закреплено правило о том, что «арендатор своими силами осуществляет управление арендованным транс- 
портным средством и его эксплуатацию, как коммерческую, так и техническую» [5]. Не вполне соответствует договору кратковременной аренды транспортного средства и положение ст. 648 ГК РФ о том, что ответственность за вред, причиненный третьим лицам транспортным средством, его механизмами, устройствами, оборудованием, несет арендатор.

Смысл договора аренды транспортных средств заключается в том, что имущество передается во владение и пользование, также арендатор получает ограниченную возможность распоряжаться объектом аренды, извлекать выгоду и использовать по своему усмотрению в течение всего срока действия договора аренды. Но по договору каршеринга арендатору не дается такой возможности. По сути, данное соглашение предоставляет лишь возможность ограниченного пользования автомобилем, так как ограничивается территория использования автомобиля, возможность парковки транспортных средств, также арендодатель может отследить перемещение автомобиля и заглушить его двигатель дистанционно [8].

Кроме того, в судебной практике по отдельным вопросам договора аренды транспортного средства без предоставления услуг по управлению и технической эксплуатации также встречаются дискуссионные аспекты, которые относятся и к каршерингу. Например, относительно правовой природы договора аренды транспортного средства без экипажа существует две позиции судов: договор признается консенсуальным («момент передачи вещи не является моментом заключения договора, т.е. отсутствие переданного имущества либо отсутствие предоплаты является неисполненной обязанностью по уже заключенному договору...» $[13,14,15$, 16]) и договор признается реальным («договор является реальным, поскольку им предусмотрено предоставление транспортного средства, а не обязанность по его предоставлению, установленная в общих положениях об аренде. СТ. 642 ГК РФ является специальной нормой по отношению к общей - ст. 606 ГК РФ, характеризующей договор аренды как консенсуальный. Таким образом, для заключения договора аренды транспортного средства, являющегося реальным договором, кроме соглашения сторон, необходима еще и передача имущества» $[17,18,19])$. Данное обстоятельство существенным образом сказывается на моменте заключения договора, и следовательно, объеме прав и обязанностей сторон, и, следовательно, нуждается в официальном разъяснении.

Таким образом, с учетом специфики договора каршеринга представляется целесообразным закрепить его дефиницию, отражающую правовую природу договора каршеринга, а также содержание в действующем гражданском законодательстве - главу 34 Гражданского кодекса РФ «Аренда транспортных средств» раздел 2 «Аренда транспортного средства без предоставления услуг по управлению и технической эксплуатации» дополнить нормами, регулирующими такой вид аренды как «Краткосрочная аренда транспортного средства (каршеринг)».

\section{ЛИТЕРАТУРА}

1. Кто пользуется каршерингом и почему он так популярен? / [Электронный ресурс]. - Режим доступа: URL:https://truesharing.ru/tp/5064/ (дата 0бращения: 10.09.2020).

2. Распоряжение Правительства РФ от 28 апреля 2018 г. № 831-р «0б утверждении Стратегии развития автомобильной промышленности Российской Федерации на период до 2025 года» // Собрание законодательства РФ. - 2018. - № 19. - Ст. 2804.

3. Распоряжение Правительства РФ от 25 марта 2020 г. № 724-р «0б утверждении Концепции обеспечения безопасности дорожного движения с участием беспилотных транспортных средств на автомобильных дорогах общего пользования» // Собрание законодательства РФ. - 2020. - № 13. - Ст. 1995.

4. Приказ Департамента транспорта и развития дорожно-транспортной инфраструктуры г. Москвы от 2 сентября 2015 г. № 61-02-283/5 / [Электронный ресурс]. - Режим доступа: URL: http://www.consultant.ru/document/cons_doc_LAW_1343245/ (дата обращения: 23.09.2020).

5. Гражданский кодекс Российской Федерации (часть вторая) от 26 января 1996 г. № 14-Ф3 (в ред. от 27 декабря 2019 г.) / [Электронный ресурс]. - Режим доступа: URL:. http://base.garant.ru/10164072/ (дата обращения: 21.09.2020).

6. Гражданский кодекс Российской Федерации (часть первая) от 30 ноября 1994 г. № 51 -Ф3 (в ред. 0 о 31 июля 2020 г.) / [Электронный ресурс]. - Режим доступа: URL: http://base.garant.ru/10164072/ (дата обращения: 21.09.2020).

7. Кориненко Р.И. Анализ неопределенности при функционировании каршерингового сервиса // Системный анализ и логистика. - 2019. - № 1. - С. 12-17 / [Электронный ресурс]. - Режим доступа: URL: https://www.elibrary.ru/item.asp?id=36954856 (дата обращения: 15.09.2020).

8. Аюшеева И.З. Гражданско-правовое регулирование отношений по совместному использованию транспортных средств на примере каршеринга // Вектор юридической науки. - 2019. - № 2. - С. 25 - 32.

9. Условия использования сервиса Яндекс. Драйв / [Электронный ресурс]. - Режим доступа: URL: https://yandex.ru/legal/drive_termsofuse/ (дата 06ращения: 11.09.2020).

10. Договор присоединения (утвержден Приказом Генерального директора А0 «Каршеринг» № 20180703-08 от 9 января 2020 года). / [Электронный ресурс]. - Режим доступа: URL: https://belkacar.ru/legal/contract.pdf?v=3.04.05 (дата обращения: 11.09.2020).

11. Постановление Пленума Верховного Суда РФ от 26 июня 2018 г. № 26 «0 некоторых вопросах применения законодательства о договоре перевозки 
автомобильным транспортом грузов, пассажиров и багажа и о договоре транспортной экспедиции» // Российская газета. - 2018. - № 142.

12. Постановление Пленума Высшего Арбитражного Суда РФ от 17 ноября 2011 г. № 73 «0б отдельных вопросах практики применения правил Гражданского кодекса Российской Федерации о договоре аренды» (в ред. от 25 декабря 2013 г.) // Вестник ВАС РФ. - 2012. - № 1.

13. Постановление Арбитражного суда Западно-Сибирского округа от 14 июля 2020 г. № Ф04-2394/2020 по делу № А81-8273/2019 / [Электронный ресурс]. Режим доступа: URL: consultant.ru/cgi/online.cgi?rnd=58212EE39CAD3D94F10FEC7\&req=doc\&base (дата обращения: 10.10.2020).

14. Постановление ФАС Московского округа от 11 мая 2006 г. № КГ-А40/3654-06 по делу № A40-48173/05-55-404 / [Электронный ресурс]. - Режим доступа: URL: consultant.ru/cgi/online.cgi?rnd=58212EE39CAD3D94F103F3BCAAF19EC7\&req=doc\&base (дата обращения: 10.10.2020).

15. Постановление Арбитражного суда Северо-Кавказского округа от 14 ноября 2017 г. № Ф08-7356/2017 по делу № А32-12772/2017 / [Электронный ресурс]. - Режим доступа: URL: consultant.ru/cgi/online.cgi?rnd=58212EE39CAD34F103Freq=doc\&base (дата обращения: 10.10.2020).

16. Постановление Арбитражного суда Уральского округа от 31 января 2017 г. № Ф09-12118/16 по делу № А47-4201/2015 / [Электронный ресурс]. - Режим доступа: URL: consultant.ru/cgi/online.cgi?rnd=3403F3BC19EC7\&req=doc\&base (дата обращения: 11.10.2020).

17. Постановление ФАС Уральского округа от 19 сентября 2002 г. № Ф09-2261/02-ГК по делу № A07-6442/02 / [Электронный ресурс]. - Режим доступа: URL: consultant.ru/cgi/online.cgi?rnd=78934219CAD3D94F1037\&req=doc\&base (дата обращения: 10.10.2020).

18. Постановление Арбитражного суда Волго-Вятского округа от 8 августа 2014 г. по делу № A11-7322/2013 / [Электронный ресурс]. - Режим доступа: URL: consultant.ru/cgi/online.cgi?rnd=9823739CAD3D9F19EC7\&req=doc\&base (дата обращения: 12.10.2020).

19. Постановление ФАС Уральского округа от 23 апреля 2009 г. № Ф09-2485/09-С4 по делу № A60-13216/2008-С11 / [Электронный ресурс]. - Режим доступа: URL: consultant.ru/cgi/online.cgi?rnd=7234521219EC7\&req=doc\&base (дата обращения: 12.10.2020).

(с Майборода Татьяна Юрьевна (xxх092020@gmail.com).

Журнал «Современная наука: актуальные проблемы теории и практики»

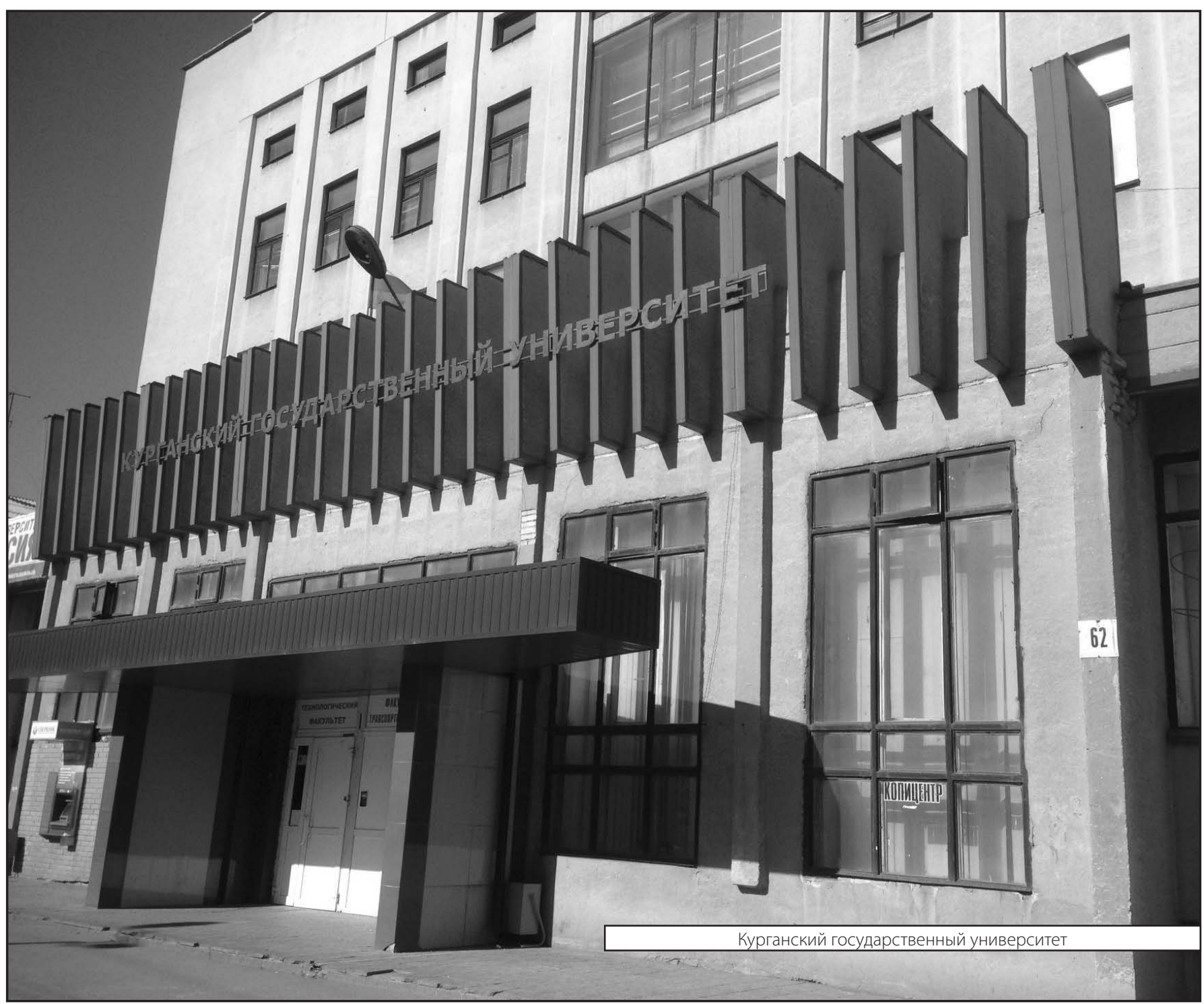

